ORIGINAL ARTICLE

ARTIGO ORIGINAL

\title{
Cost-minimization and budget impact analysis of certolizumab pegol for patients with Crohn's disease, moderate or severe, with relapse after conventional treatment from the perspective of the Brazilian private payer
}

\author{
Análises de custo-minimização e impacto orçamentário do \\ certolizumabe pegol para pacientes com doença de Crohn \\ moderada a grave com falha ao tratamento convencional, \\ sob a perspectiva do pagador privado no Brasil
}

Ricardo Papaléo Rosim', Andreas de Souza Duva', André Fabre Ballalai Ferraz', Arcangela Valle², Emese Tóth³ ${ }^{3}$ Samara Ferguson ${ }^{4}$, Érico V. S. Carmo²

DOI: $10.21115 /$ JBES.v9.n1.p44-53

\section{Keywords:}

Crohn's disease, certolizumab pegol, health evaluation, infliximab, adalimumab, biological products

\section{Palavras-chave:}

doença de Crohn, certolizumabe pegol, avaliação de tecnologias em saúde, infliximabe; adalimumabe, produtos biológicos

\begin{abstract}
Objectives: Budget impact and cost-effectiveness analysis are often required by payers when discussing drug reimbursement. We hereby present a cost-minimization (CMA) and budget impact analysis (BIA) regarding the incorporation of certolizumab pegol (CZP) for the treatment of patients with Crohn's disease, a debilitating condition that affects the digestive tract. Methods: Considering that the scientific literature demonstrates CZP as effective as the alternatives (infliximab and adalimumab), a CMA was conducted, including a Markov 10-year time horizon modeling. Focusing on the assumptions for both CMA and BIA, a total of 36 stakeholders from the private sector were surveyed regarding treatment and disease-related costs. For the BIA, drug acquisition costs, administration costs, no population growth and an immunobiologic drug (bDMARD) switching rate of 5\% were also considered. We assumed that CZP would gradually gain market share until it reaches $20 \%$ of new or switching patients in the fourth year. In addition, probability sensitivity analyses were performed. Results: In the cost-minimization, the calculated costs for 10-year treatment were BRL149k (infliximab); BRL118k (adalimumab) and BRL83k (CZP). Probabilistic sensitivity analysis was conducted with 1,000 random simulations, with CZP being less costly than its comparators in all simulations. Additionally, the BIA result indicates that CZP is a cost-saving intervention, with a predicted five-year impact of BRL317k for every 100-patient cohort. Conclusions: Certolizumab pegol was shown to be not only effective but also a cost-saving drug when compared to other anti-TNF drugs available for the Brazilian private healthcare system.
\end{abstract}

\section{RESUMO}

Objetivos: Análises de impacto orçamentário e de custo-efetividade são, com frequência, exigidas por pagadores para a decisão sobre incorporação de drogas. Por esse motivo, apresentaremos uma análise de custo-minimização e de impacto orçamentário do certolizumabe pegol (CZP) para o tratamento de pacientes com doença de Crohn, doença crônica e debilitante que afeta o trato digestivo. Métodos: Trinta e seis pagadores privados foram entrevistados para que fosse possível

\footnotetext{
Received on: 02/26/2017. Approved for publication on: 04/03/2017.

1. IMS Health, São Paulo, SP, Brazil.

2. UCB Biopharma, São Paulo, SP, Brazil.

3. UCB Biopharma Sprl. Brussels, Belgium.

4. UCB Pharma Ltd., Slough, England.

Information on support received as financing, equipment or drugs: Ricardo Papaléo Rosim, Andreas de Souza Duva and André Fabre Ballalai Ferraz are employees of IMS Health, which was sponsored by the company that markets the drug certolizumab pegol, UCB Biopharma, to perform these analyses. Arcangela Valle and Érico Carmo are employees of UCB Biopharma.

Corresponding author: Érico V. S. Carmo. Av. Brigadeiro Faria Lima, 4300 - Itaim Bibi, São Paulo, SP, Brazil. 04538-132. Telephone: (+55 11) 3847-1780 / (+ 55 11) 98378-1299. E-mail: erico.carmo@ucb.com
} 
compreender os custos de tratamento e aqueles relacionados à doença. Para a análise de impacto orçamentário, foram assumidos: custos de aquisição e administração das drogas, nenhuma taxa de crescimento populacional, taxa de troca de medicamento biológico (bDMARD) de 5\% e market share de 20\% para o CZP em seu pico. Visto que o CZP é tão eficaz e seguro quanto os comparadores disponíveis, optou-se pela análise de custo-minimização, assumindo horizonte temporal de 10 anos.

Resultados: A análise de impacto orçamentário mostra que o CZP é capaz de gerar redução de custos no valor de R\$317 mil em cinco anos, para cada cem pacientes. Para a custo-minimização, os custos calculados no horizonte de dez anos foram: R\$ 149 mil para o infliximabe; R\$ 118 mil para o adalimumabe e R\$ 83 mil para o CZP. A análise de sensibilidade probabilística mostrou CZP menos custoso em 100\% das 1.000 simulações. Conclusões: Certolizumabe pegol mostrou-se não apenas efetivo, mas também uma opção que pode gerar redução de custos quando comparada às outras drogas biológicas no Brasil sob a perspectiva do pagador privado.

\section{Introduction}

Crohn's disease (CD) is a highly debilitating disease that affects the gastrointestinal tract (Shanahan, 2002), with a prevalence that highly varies, depending on the world region, but that has been estimated generally at 5 cases in every 100,000 inhabitants (Loftus et al., 2002; Shivananda et al., 1996; Trallori et al., 1996). Some of the main disease symptoms are diarrhea, abdominal pain and abdominal cramping (Joshua-Gotlib et al., 2004). In addition to symptoms directly related to Crohn's disease, other complications also occur. These complications may or not be related to bowel inflammation. The most common is gastrointestinal tract obstruction, which usually occurs in the small bowel (Loftus et al., 1998).

Certolizumab pegol is a recombinant, humanized, polyethylene glycol-conjugated antigen-binding antibody fragment (Fab') with specificity for human TNF-alfa. Its efficacy and safety, according to various systematic reviews and meta-analyses using its clinical trials as the basis, as well as trials of its alternatives adalimumab and infliximab, are considered equivalent, thus justifying its use in moderate to severe Crohn's disease patients who are unresponsive or with poor response to synthetic disease-modifying drugs (Shao et al., 2009; Singh et al., 2014; Stidham et al., 2014). The drug is currently approved by the Brazilian Health Surveillance Agency (ANVISA) for the treatment of moderate to severe CD not responding to conventional treatment, among other indications (ANVISA, 2016).

In recent years, the literature has demonstrated a special interest in the use of biological drugs, including for CD. The study by Stidham et al. (2014) has indirectly evaluated adalimumab, infliximab and certolizumab pegol in a systematic review and demonstrated that there is no statistical difference in terms of efficacy superiority between them. Additionally, Nikfar et al. (Nikfar et al., 2013) demonstrated that there are no statistically significant differences between the probabilities for placebo's and certolizumab pegol's adverse events occurring. Furthermore, Peyrin-Biroulet et al. (Peyrin-Biroulet et al., 2008), in their meta-analysis, concluded that adverse events from anti-TNF agent class, as a whole, are not more frequent than adverse events in placebo patients.

The access to care and early intervention to treat inflammatory disorders such as CD can be very difficult to achieve in Latin America, including Brazil, which has been facing challenges related to the allocation of scarce resources for the management of this and other chronic conditions (Burgos-Vargas et al, 2013; Tundia et al., 2016). Additionally, the Brazilian Supplementary Health Agency (ANS), subordinate to the Ministry of Health, is responsible for regulating private health insurance plans in Brazil and establishing the mandatory minimum coverage of health technologies by these plans. In this context, ANS set forth in 2016 that "subcutaneous immune biological therapy for rheumatoid arthritis, psoriatic arthritis, Crohn's disease and ankylosing spondylitis therapy", as well as intravenous immune biological therapies for the same purposes, should be reimbursed by insurance. However, when performing this study, there were two immune biological drugs available and approved for Crohn's disease indication, in addition to certolizumab pegol itself: infliximab and adalimumab (ANS, 2016).

Considering this mandatory coverage by health insurance companies, the purpose of this study was to perform a pharmacoeconomic assessment of certolizumab pegol compared to infliximab and adalimumab. Further taking into consideration scientific literature showing that drug efficacy and safety do not have statistically significant differences (Shao et al., 2009; Nikfar et al., 2013; Singh et al., 2014; Stidham et al. 2014), a cost-minimization analysis was chosen. Moreover, we carried out a budget impact analysis. All these analyses will be shown from the perspective of a Brazilian private payer.

\section{Methods}

\section{Cost-minimization model}

The objective of this analysis was to estimate the potential reduction in costs by the introduction of CZP as an anti-TNF option in protocols for CD treatment. Cost-minimization analyses are often performed by estimating the treat- 
ment cost based only on the drug itself. However, in some cases, the development of a more detailed pharmacoeconomic model may be chosen (Miyazaki et al., 2009). Since CD may cause disease states for the patient generating high costs in addition to drugs, such as the need for surgery, a more detailed analysis may be appropriate.

Most cost-effectiveness and cost-utility studies for Crohn's disease used CDAl criterion to go further or to leave the treatment (Blackhouse et al., 2012; Bodger, 2011; Bodger et al., 2009; Kaplan et al., 2007; Lindsay et al., 2008). However, the structures of different models differ somewhat from each other. A study from a group of Canadian researchers based on the Markov model (Blackhouse et al., 2012) was chosen to be the foundation for development since this was the model better reflecting the clinical reality seen in Brazil once the patient's journey is similar to the recommendation made by the Brazilian National Clinical Guideline (PCDT) and more truthfully approximating the real costs generated by patients during the disease course. The model was developed in Microsoft Excel software.

\section{Model perspective}

We assumed the perspective of payers in the Brazilian private healthcare system.

\section{Population}

Simulation was performed assuming a hypothetical cohort of 1,000 CD patients, with a mean weight of 65 kilos and a mean age of 35 years. These assumptions were taken considering the patient profile observed in Brazilian Public Health Database, the DATASUS.

\section{Time horizon and cycle length}

CD is a patient life-lasting chronic disease (Carter et al., 2004); however, this rarely responds to treatment with the same drug for a period longer than 10 years. This information may be concluded from the fact that most patients end up undergoing surgery within a period up to ten years (Bernell et al., 2000; Carter et al., 2004). In order to mitigate the influence of cost reduction caused by standard therapy after biological drug failure, a time period of ten years was assumed for this analysis. Each cycle lasts six weeks, due to the large number of results from clinical trials in this period.

\section{Health states}

Health states in Markov's model were the following: active disease [patient not responding to conventional treatment (MMCD), failure, conventional treatment], clinical remission, response, surgery, surgical remission, death (Figure 1). In this model, all patients are a status after synthetic MMCD failure, when they start anti-TNF therapy. At this status, the patient may experience a response, remission of treatment failure. At

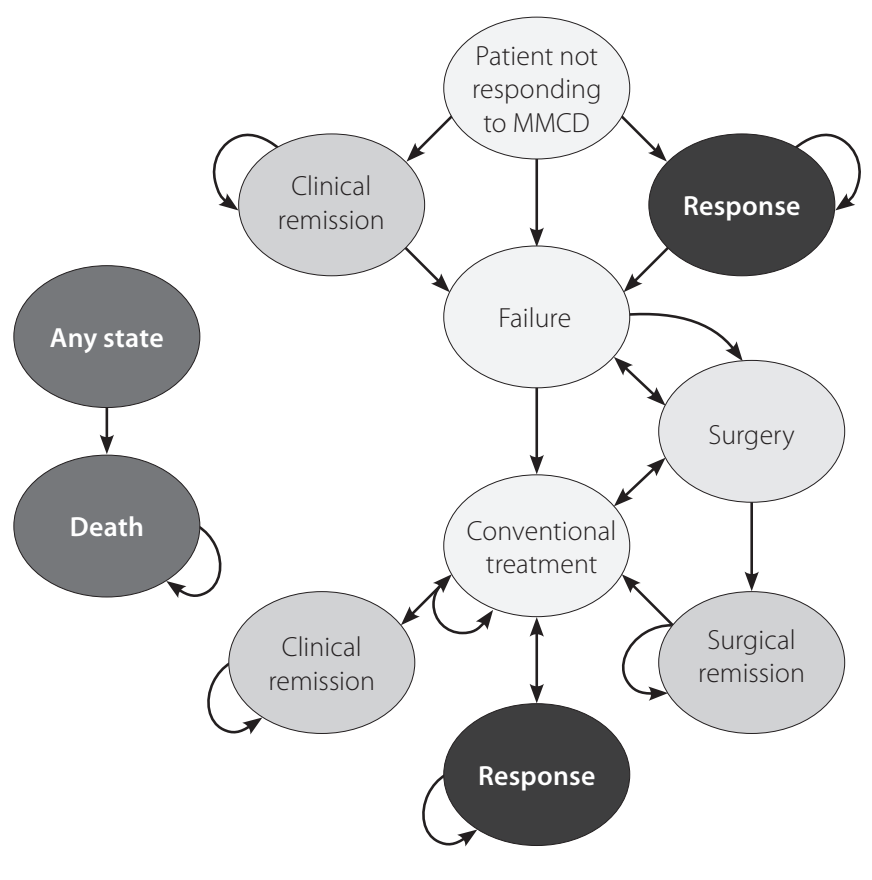

Figure 1. Markov's model structure developed for costminimization analysis.

any time, failure may occur during response and remission status. After this possible treatment failure, some patients undergo surgery in some cases resulting in remission. However, a good part of patients does not undergo surgery, resuming treatment with synthetic MMCD. It is assumed that the patient may die at any status.

\section{Transition probabilities}

Response and remission assessment is made based on Crohn's disease activity index (CDAI). In the event of a decrease over 100 points in CDAl, a response is assumed. If the index falls for a score lower than 150, remission is assumed. Witching probabilities were estimated from the meta-analysis by Singh et al. (Singh et al., 2014), with probabilities of response, remission and response and remission maintenance in control groups being obtained in Precise 1 study (Sandborn et al.). The probabilities are shown in Table 1. The probability of surgical remission was obtained from Siverstein et al.'s study (Silverstein et al., 1999) and adapted for the model cycle duration. The probability for a patient with active disease to proceed to the surgery state estimated is $0.45 \%$ per cycle (Feagan et al., 2008). Based on this same study (Feagan et al., 2008), hospitalization probability is established at $1.9 \%$ in patients with drug treatment failure. In addition, the relative risks and respective response ratios are presented in Table 2.

\section{Mortality}

Mortality rates were obtained in mortality tables from Instituto Brasileiro de Geografia e Estatística [Brazilian Institute 
Table 1. Probabilities of switching between states of cost-minimization model

\begin{tabular}{|c|c|c|c|c|}
\hline & Remission & Response & Remission maintenance & Response maintenance \\
\hline Conventional treatment & $17 \%$ & $9 \%$ & $58 \%$ & $65 \%$ \\
\hline Infliximab & $50 \%$ & $31 \%$ & $80 \%$ & $86 \%$ \\
\hline Adalimumab & $43 \%$ & $14 \%$ & $84 \%$ & $83 \%$ \\
\hline Certolizumab pegol & $21 \%$ & $11 \%$ & $76 \%$ & $83 \%$ \\
\hline Surgery & $42 \%$ & $0 \%$ & $98 \%$ & $0 \%$ \\
\hline
\end{tabular}

Table 2. Relative risks of response and remission considered

\begin{tabular}{lccrr}
\hline & Remission & Response & Remission maintenance & Response maintenance \\
\hline Infliximab & $3,7(0,87-15,8)$ & $4,01(1,29-12,44)$ & $1,86(1,21-2,86)$ & $1,69(1,19-2,41)$ \\
\hline Adalimumab & $2,94(1,86-4,66)$ & $1,71(1,31-2,24)$ & $2,06(1,5-2,82)$ & $1,69(1,19-2,41)$ \\
\hline Certolizumab pegol & $1,22(1,00-1,50)$ & $1,25(1,07-1,46)$ & $1,62(1,3-2,02)$ & $1,64(1,37-1,97)$ \\
\hline
\end{tabular}

of Geography and Statistics (IBGE). The multiplying standardized mortality ratio (SMR) considered for patients with active disease (out of remission and response states) was 1.85 (Wolters et al., 2006). By means of regressions, it was possible to establish an equation for the mortality rate in the overall population (1) and another for the mortality rate in active disease population (2). The active disease comprises all states where the patient is not in clinical remission nor surgical remission:

- mortality $=0.00020 e^{0.06815 i t y}$

- mortality $=0.00037 e^{0.06815 i t y}$

\section{Discounting}

A discount rate of 5\% per year was used (Brasil, 2009).

\section{Alternatives}

As alternatives, we have chosen adalimumab and infliximab based on the quality of data available in scientific literature. In addition, these anti-TNFs have been present Brazilian market with the biggest market shares.

Table 3. Prices and dosing regimens

\begin{tabular}{|c|c|c|}
\hline Item & Acquisition price & Dosage regimen \\
\hline $\begin{array}{l}\text { Certolizumab } \\
\text { pegol } 200 \text { mg, } \\
\text { two units }\end{array}$ & BRL 1,794.76 & $\begin{array}{c}400 \mathrm{mg} \text { in weeks } 0,2 \text { and } \\
4 \text { and afterwards } 400 \mathrm{mg} \\
\text { at every four weeks }\end{array}$ \\
\hline $\begin{array}{l}\text { Adalimumab } \\
40 \text { mg, two units }\end{array}$ & BRL 4,957.76 & $\begin{array}{c}160 \mathrm{mg} \text { in week 0,80 mg } \\
\text { in week 2,40 mg in week } \\
4 \text { and afterwards } 40 \mathrm{mg} \\
\text { at every two weeks }\end{array}$ \\
\hline $\begin{array}{l}\text { Infliximab } \\
10 \text { mg/ml - } 10 \mathrm{ml}\end{array}$ & BRL 3,308.15 & $\begin{array}{c}5 \text { mg per kilogram } \\
\text { in weeks 0, } 2 \text { and } 6 . \\
\text { Afterwards, } 5 \text { mg } \\
\text { per kilogram at } \\
\text { every eight weeks }\end{array}$ \\
\hline
\end{tabular}

\section{Estimation of costs}

The costs considered in the model were the cost of obtaining the drug, infusion cost for infliximab, training cost to use subcutaneous drug for adalimumab and certolizumab pegol, cost of surgery, cost of hospitalization and cost of tests.

In order to obtain the effective price of medications and other costs paid by institutions, a research was carried out with 21 private health institutions (among hospitals and clinics) and 15 healthcare insurance companies. The mean values found are shown in Table 3, along with the dosing regimen of each drug considered in the analysis. This approach is needed considering that there is no published price or database publicly available for the private market in Brazil.

With drug costs available based on the previous research, it was possible to estimate the total dosing cost (infusion cost for infliximab and training on a subcutaneous drug use for the others). For that, during the same research we also interviewed 15 gastroenterologists and 15 nurses from the selected institutions, aiming at determining the resources used during patient management. To obtain the unit costs, the same research was carried out with healthcare institutions already previously described. These costs and resource use are explained in Table 4.

From this data, it was possible to calculate the total cost of acquisition and dosing of each drug (Table 5).

The calculation and test costs were made based on data obtained in the same research with healthcare professionals and institutions. The costs and frequency of performance of these tests in patients being treated with anti-TNF drugs are shown in Table 6. For conventional treatment with synthetic drugs, tests were assumed to be the same; this was, however, without the need for a chest X-ray, tuberculin test, HbsAG and anti-HCV. Thus, the values obtained to estimate the disease monitoring are shown in Table 7.

Also based on the already mentioned research, the cost of hospitalization was estimated: six days of hospitalization 
Table 4. Resources and costs for infusion and training

\begin{tabular}{lcc}
\hline Item & Unit value & Use \\
\hline Infusion pump & BRL 23.05/hour & 1.5 hours per patient \\
\hline Scalp & BRL 2.52/unit & 0.8 per patient \\
\hline Catheter & BRL 7.67/unit & 1 per patient \\
\hline Alcohol swab & BRL 0.54/unit & 1.4 per patient \\
\hline Anti-histamine & BRL 12.26/unit & 0.5 per patient \\
\hline Pair of gloves & BRL 1.60/paur & 1.4 per patient \\
\hline Nurse & BRL 53.64/hour & 1.5 hours, assisting 4.2 patients simultaneously \\
\hline Gastroenterologist & BRL 224.00/hour & 2.3 hours, assisting 4.2 patients simultaneously \\
\hline
\end{tabular}

Table 5. Total cost (BRL) of drug acquisition and dosing

\begin{tabular}{lccccc}
\hline & Acquisition price & $\begin{array}{c}\text { First year } \\
\text { administration cost }\end{array}$ & $\begin{array}{c}\text { Subsequent year } \\
\text { administration cost }\end{array}$ & First year total cost & $\begin{array}{c}\text { Subsequent } \\
\text { years total cost }\end{array}$ \\
\hline Certolizumab pegol & $1,794.76$ & 166.28 & 166.28 & $27,087.66$ & $23,498.14$ \\
\hline Adalimumab & $4,957.76$ & 166.28 & 166.28 & $77,011.53$ & $64,617.13$ \\
\hline Infliximab & $3,308.15$ & $1,750.15$ & $1,531.38$ & $107,611.06$ & $80,927.06$ \\
\hline
\end{tabular}

Table 6. Values of tests and number of tests performed for patients treated with anti-TNF

\begin{tabular}{lccc}
\hline Test & $\begin{array}{c}\text { Value } \\
\text { (BRL) }\end{array}$ & $\begin{array}{c}\text { Number of } \\
\text { tests - first } \\
\text { semester }\end{array}$ & $\begin{array}{c}\text { Number of } \\
\text { tests - other } \\
\text { semesters }\end{array}$ \\
\hline CBC & 42.31 & 2.9 & 2.1 \\
\hline Chest X-ray & 113.64 & 0.9 & 0.9 \\
\hline Tuberculin test & 66.90 & 1.0 & 0.5 \\
\hline ALT/SGPT & 46.78 & 2.2 & 1.5 \\
\hline AST/SGOT & 43.94 & 2.2 & 1.5 \\
\hline Endoscopy & 489.57 & 0.6 & 0.5 \\
\hline Colonoscopy & 547.69 & 0.9 & 0.8 \\
\hline $\begin{array}{l}\text { Cholesterol } \\
\text { and fractions }\end{array}$ & 33.40 & 1.1 & 0.8 \\
\hline Triglycerides & 44.76 & 1.1 & 0.8 \\
\hline ESR & 34.25 & 2.3 & 1.6 \\
\hline $\begin{array}{l}\text { C-reactive } \\
\text { protein }\end{array}$ & 53.72 & 2.3 & 1.9 \\
\hline HbsAG & 43.81 & 1.0 & 0.4 \\
\hline Anti-HCV & 58.29 & 0.9 & 0.5 \\
\hline Rheumatoid & 77.51 & 0.4 & 0.5 \\
factor & & & \\
\hline
\end{tabular}

Table 7. Total cost (BRL) of tests to monitor the disease

\begin{tabular}{lcc}
\hline & First year & Other years \\
\hline Anti-TNF & $3,042.12$ & $2,696.83$ \\
\hline $\begin{array}{l}\text { Conventional } \\
\text { therapy }\end{array}$ & $2,594.28$ & $2,332.04$ \\
\hline
\end{tabular}

was taken into consideration per hospitalization event, with a daily cost of hospital room at BRL 1,231 and a nurse hour cost at BRL 53.64.

\section{Budget impact model}

The objective of this analysis is to demonstrate the net budget impact of the adoption of CZP by modeling a hypothetical cohort of 100 patients which could be applied at health company level of the supplementary health system in Brazil. A budget impact model was built in Microsoft Excel software and follows the following logics. Patients enrolled at each year in the model may take any of the biological drugs, as well as those switching biological therapy, following the defined market share for each drug. Patients not switching therapy and not discontinuing biological treatment until the time period continue to take the same drug throughout the five-year period (2016-2020) (Brasil, 2009). Due to the lack of data from the supplementary health system for the dynamics of the population receiving biological treatment for Crohn's disease, it was assumed that the dynamics in the private system would be similar to that in the public health system. In addition, there is no patient management difference between those systems that could impact the assumption. Therefore, data from the Brazilian Public Health Database DATASUS were used so that it was possible to project the population size within the five-year time frame.

\section{Patient population}

The patient filter was made based on the International Classification of Diseases and Health-Related Problems (ICD 10). 
ICD 10 codes chosen to perform these analyses were the following:

- K500: Small bowel Crohn's disease

- K501: Large bowel Crohn's disease

- K508: Other types of Crohn's disease

\section{Patient dynamics}

The calculation of new patient enrollment rate in the model was made by comparing the number of patients starting their treatment with a biological drug in the year of analysis and the total patients from the previous year. An illustrative example may be seen in Table 8 . By using the new patient enrollment history, the following equation was built for the calculation of new patient rate at each year: $y=0.7411 x^{-0.466}$ , wherein $y$ represents the enrollment rate according to the year and $x$ variable represents the year being analyzed, with 2011 being year 1, 2012 being year 2, successively reaching year 10 in 2020.

Calculating the arithmetic mean of enrollment rates between 2015 and 2020, the mean enrollment rate of 31\% per each year is reached and applied in the budget impact model.

The switching rate is estimated by dividing the number of patients receiving both infliximab and adalimumab in the same year by the total number of patients receiving biological drugs in the same year. The rate assumed is $5 \%$ a year based on data observed from DATASUS.

The patient withdrawal rate from the model was calculated by dividing the number of patients who no longer received biological drugs (i.e., who received them in the previous year and did not receive in the year of analysis) by the total number of patients in treatment in the previous year.

The yearly rates observed in DATASUS ranged from 18\% to $24 \%$. Since the rate varies a little at each year, the 2015 rate of $19 \%$ was used. Possible variations will be treated in the sensitivity analysis.

\section{Market share}

Since there is a potential late incorporation compared to other drugs already available for a few years by the Brazilian health system, certolizumab pegol is expected not to reach a market share close to adalimumab and infliximab. It is estimated that in 2020 certolizumab pegol would have 20\% of market share in new patients or patients switching biological drugs, a year when its share would peak. A theoretical adop-

Table 8. Illustrative example of methodology of estimation of enrollment rate in budget impact model

\begin{tabular}{ll} 
Total number of patients in 2010 (A) & 2.931 \\
\hline Patients starting treatment in 2011 (B) & 2.265 \\
\hline Enrollment rate (B)/(A) & $77 \%$
\end{tabular}

tion curve was taken into consideration, based on examples from other drugs, represented in Figure 2.

For this analysis only the drug acquisition and dosing costs were used (infusion or training to use a subcutaneous drug), consistent with the approach used for the cost-minimization analysis.

\section{Sensitivity analysis for both models}

Trying to minimize the effects of uncertain parameters contained in cost-minimization and budget impact analysis, probability sensitivity analyses were performed. Considering the potentially high variability of drug prices, those were assumed to vary from $50 \%$ to $120 \%$ of values used in the basis case. For other costs, a standard deviation of $20 \%$ was assumed.

Population parameters were also a sensitivity analysis target for the cost-minimization analysis, and its variation is shown in Table 9.

Parameters considered in sensitivity analysis of budget impact model are shown in Table 10 and were simulated as a thousand random events.

\section{Results}

\section{Cost-minimization analysis}

In this cost-minimization analysis with a ten-year timeframe, the total cost of certolizumab pegol was significantly lower than its alternatives, being $44 \%$ lower than the treatment cost with infliximab and 29\% lower than adalimumab cost. Total costs of treatments seen with infliximab, adalimumab and certolizumab pegol were as follows, respectively: $R \$$ 149,223; R\$ 117,680; R\$ 83,145 (Figure 3).

\section{Sensitivity analysis for cost-minimization analysis}

It was seen that in $100 \%$ of these cases certolizumab pegol was shown as less costly than the other drugs. The medians, with a $95 \%$ confidence interval $(95 \%$ Cl) for treatments with infliximab, adalimumab and certolizumab pegol, were as follows, respectively: BRL 142,028 (100,966 - 200,484); BRL 117,517 (92,160 - 147,199); BRL 83,283 (63,085 - 107,649) (Figure 4). It

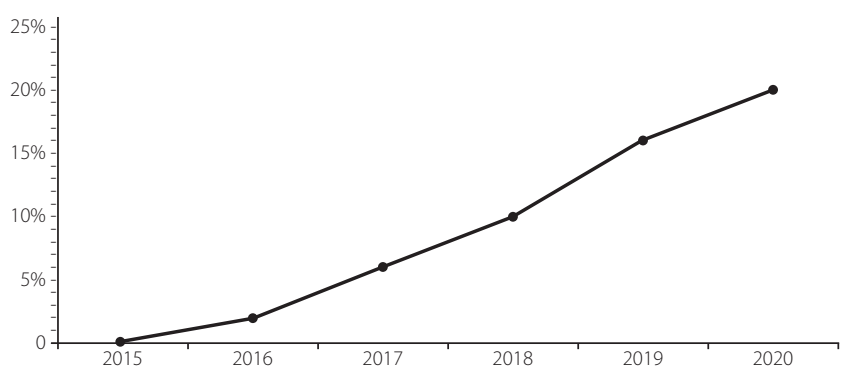

Figure 2. Adoption curve assumed for certolizumab pegol for budget impact estimation. 
Table 9. Variables considered in cost-minimization sensitivity analysis (clinical and population variables)

\begin{tabular}{|c|c|c|c|c|}
\hline Clinical endpoints & Mean & Lower bound & Upper bound & Type of distribution \\
\hline Relative remission risk - infliximab & 3.70 & 0.87 & 15.80 & Lognormal \\
\hline Relative response risk - infliximab & 4.01 & 1.29 & 12.44 & Lognormal \\
\hline Relative remission maintenance risk - infliximab & 1.86 & 1.21 & 2.86 & Lognormal \\
\hline Relative response maintenance risk - infliximab & 1.69 & 1.19 & 2.41 & Lognormal \\
\hline Relative remission risk - adalimumab & 2.94 & 1.86 & 4.66 & Lognormal \\
\hline Relative response risk - adalimumab & 1.71 & 1.31 & 2.24 & Lognormal \\
\hline Relative remission maintenance risk - adalimumab & 2.06 & 1.50 & 2.82 & Lognormal \\
\hline Relative response maintenance risk - adalimumab & 1.69 & 1.19 & 2.41 & Lognormal \\
\hline Relative remission risk - certolizumab & 1.22 & 1.00 & 1.50 & Lognormal \\
\hline Relative response risk - certolizumab & 1.25 & 1.07 & 1.46 & Lognormal \\
\hline Relative remission maintenance risk - certolizumab & 1.62 & 1.30 & 2.02 & Lognormal \\
\hline Relative response maintenance risk - certolizumab & 1.64 & 1.37 & 1.97 & Lognormal \\
\hline SMR & 1.85 & 1.30 & 2.55 & Lognormal \\
\hline Probability of surgery & $0.45 \%$ & $0.3 \%$ & $0.7 \%$ & Lognormal \\
\hline Values & Mean & \multicolumn{2}{|c|}{ Assumed standard deviation } & Type of distribution \\
\hline Cohort age & 35 & \multicolumn{2}{|c|}{10} & Gamma \\
\hline Discount rate & $5 \%$ & \multicolumn{2}{|c|}{$2,5 \%$} & Beta \\
\hline Patient weight & 65 & \multicolumn{2}{|c|}{14} & Gamma \\
\hline
\end{tabular}

Table 10. Variables considered in sensitivity analysis of budget impact (population variables)

\begin{tabular}{lccc}
\hline Variable & Mean & $\begin{array}{l}\text { Standard } \\
\text { deviation }\end{array}$ & $\begin{array}{c}\text { Type of } \\
\text { distribution }\end{array}$ \\
\hline $\begin{array}{l}\text { Patient } \\
\text { weight }(\mathrm{kg})\end{array}$ & 65 & 14 & Gamma \\
\hline $\begin{array}{l}\text { Certolizumab } \\
\text { peak share }\end{array}$ & $20 \%$ & $15 \%$ & Beta \\
\hline $\begin{array}{l}\text { Withdrawal } \\
\text { rate }\end{array}$ & $19 \%$ & $6 \%$ & Beta \\
\hline $\begin{array}{l}\text { Switching rate } \\
\begin{array}{l}\text { Enrollment } \\
\text { rate }\end{array}\end{array}$ & $5 \%$ & $2 \%$ & Beta \\
\hline
\end{tabular}

was further seen that when the cost of certolizumab pegol is close to its $\mathrm{Cl}$ 95\% upper bound, the costs with its alternatives remain above it.

Certolizumab pegol was estimated to be at least 16\% less costly than infliximab and $12 \%$ less costly than adalimumab, and at most $65 \%$ less costly than infliximab and $49 \%$ less costly than adalimumab.

\section{Budget impact analysis}

From data assumed and described under methods, the total number of patients by year was estimated, ranging from 112 in 2016 to 178 in 2020, with 58 of these patients in the last year being new patients (i.e., starting biological therapy) or switching treatment (Figure 5).
149.223

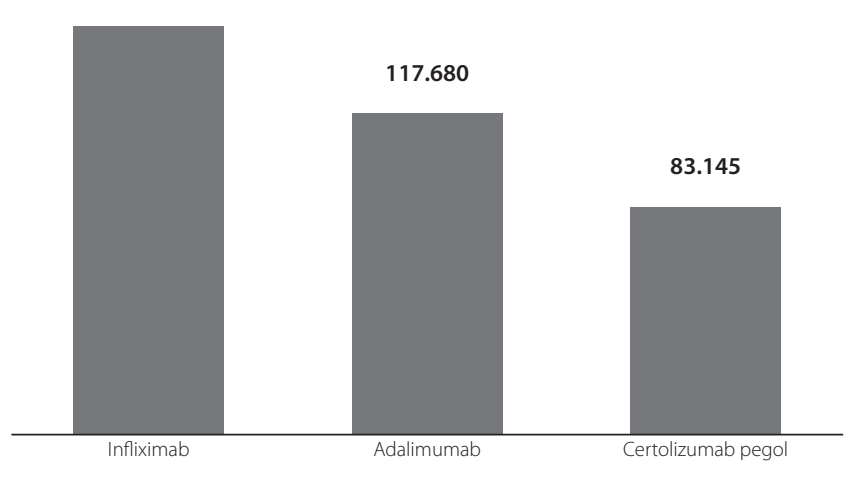

Figure 3. Cost of treatment per intervention (cost-minimization analysis result).

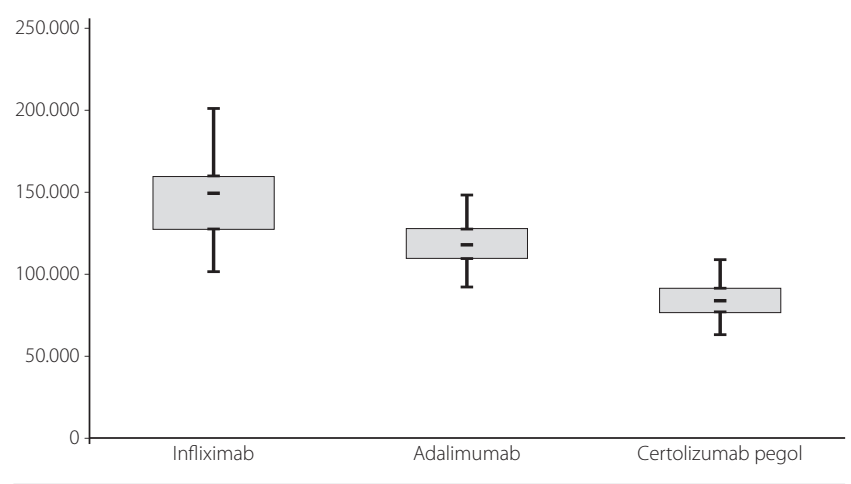

Figure 4. Result of cost-minimization analysis sensitivity analysis (Results in BRL, cost per patient. Traces represent from bottom to top: $95 \%$ Cl lower bound; first quartile; median; third quartile; 95\% Cl upper bound). 
It is afterwards possible to estimate the number of patients per intervention, at each year, in the scenarios with and without certolizumab pegol as an add-on (Figure 6).

Lastly, it is estimated that cost reduction caused by adding certolizumab pegol by a private health company within five years for every 100 patients treated with biological anti-TNF drugs for CD is BRL 2.7 million. This amount ranges from BRL 47,000 in the first year to BRL 1.3 million in the last year (Figure 7).

\section{Sensitivity analysis for budget impact analysis}

We observed that there is approximately a $50 \%$ probability that the cost saved by adding certolizumab pegol within five

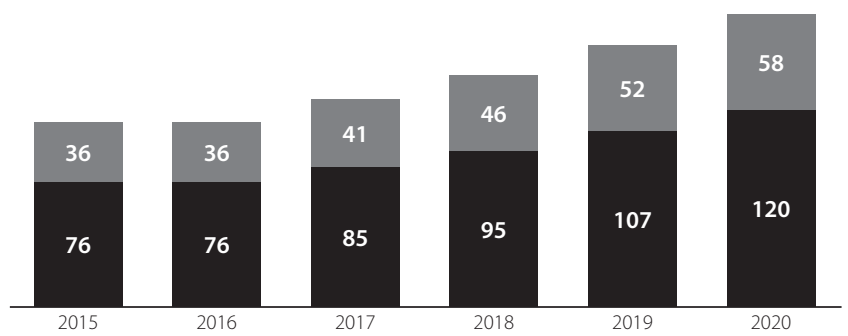

Patients in treatment since at least the previous year

New patients or patients switching biologicals

Figure 5. Number of patients per year in budget impact analysis. years, considering an initial population of 100 people, is above BRL 2 million (Figure 8). There was a cost reduction in all scenarios simulated.

\section{Discussion}

$\mathrm{CD}$ is not only disabling for the patient but is also generating considerable costs, both for the payer and for society (Ekbom \& Blomqvist, 1998; Silverstein et al., 1999). Additionally, Tundia et al. (2016) have demonstrated that in Brazil biological drugs represent more than $90 \%$ of CD patient treatment drug costs. Under this perspective, the quest for a treatment, at least, as effective and less costly compared to others currently covered by companies becomes key to guaranteeing the financial sustainability of the system. This is required especially if we consider the current scenario of growing casuistic and decreasing profitability of supplementary healthcare insurance companies (Albuquerque et al., 2008), in addition to the increased population life expectancy (Azevedo, 2010).

Certolizumab pegol in several studies has been shown as effective and safe as other anti-TNF agents available to treat CD (Shao et al., 2009; Singh et al., 2014). On the other hand, the results of this study aim to fill the blank existing in the current literature regarding the lack of more detailed economic

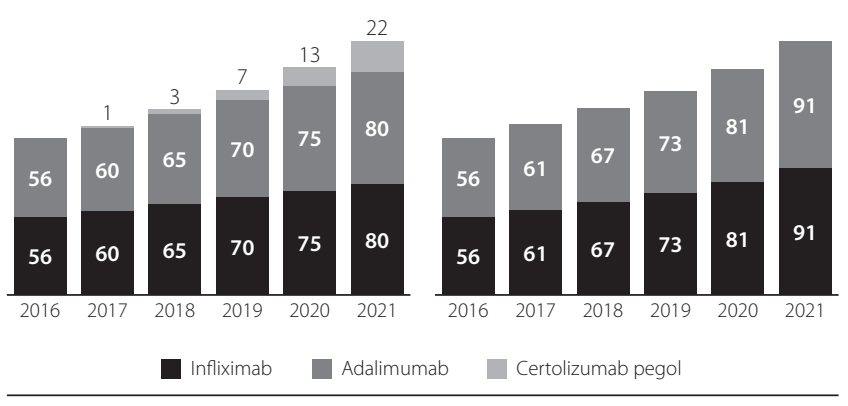

Figure 6. Comparison: Number of patients per intervention in scenarios with and without add-on.

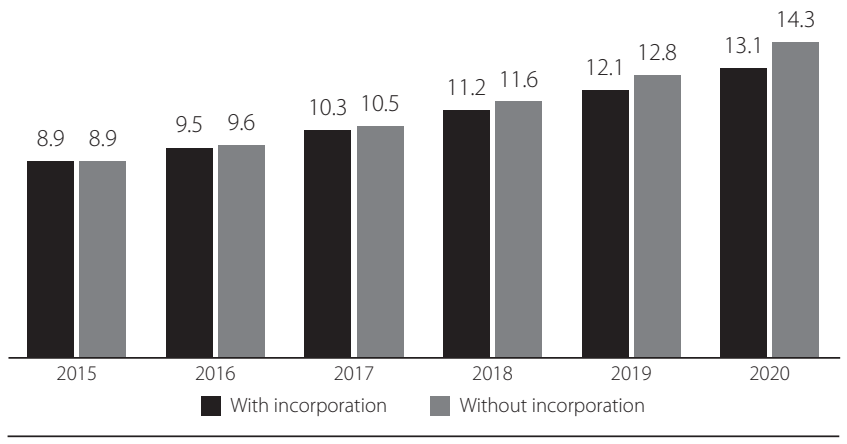

Figure 7. Total cost: Comparison between scenarios with and without incorporation (in millions of Brazilian Reais).

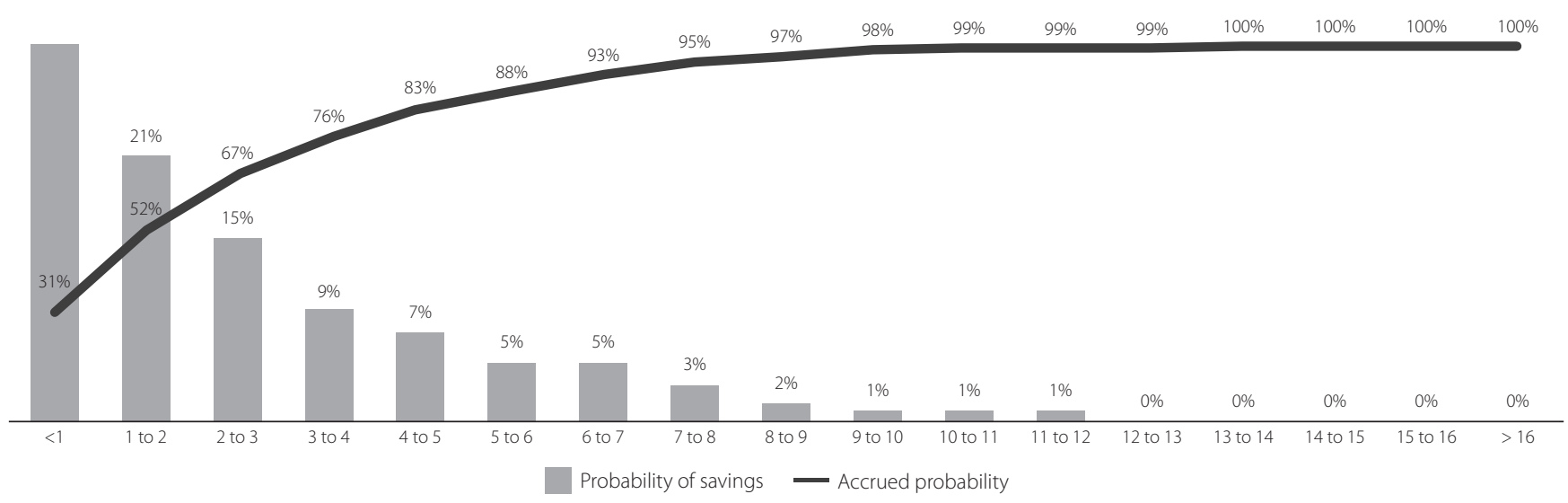

Figure 8. Probabilities of savings for supplementary healthcare company (value ranges in millions of Brazilian Reais). 
analyses developed under the Brazilian payer's perspective, either public or private.

Additionally, it is important to have in mind that the concept of saving in the health system can also be considered an additional budget to provide access to patients who for some reason have not been treated.

Although this study considers several uncertain parameters, it can be considered to be truthful considering the results of the probability sensitivity analyses performed. It supports those obtained from the deterministic analysis. Another possible limitation of this analysis is the absence of vedolizumab, a product launched in Brazil during the course of this study. However, we believe that its inclusion as an additional alternative would only increase the uncertainty of results. Considering that its market share and prices charged may not yet be correctly measured and, thus, are estimated with a poor basis in real world data, vedolizumab is still a product with low adoption by companies and hospitals. Another possible limitation is the fact that DATASUS only has data from patients assisted in the public health system and also the anti-TNFs. There is no official database from private health system available, which in some way could lead to different assumptions regarding market share once that the reimbursement level differs from the public health system.

\section{Conclusions}

When observing the results obtained by both cost-minimization analysis and budget impact analysis, it was concluded that the adoption of certolizumab pegol by Brazilian healthcare insurance companies has a positive impact on its budget, considering the low cost when compared to other anti-TNF agents without any prejudice regarding efficacy and safety parameters.

\section{References}

Albuquerque C, Piovesan MF, Santos IS, Martins ACM, Fonseca AL, Sasson D, et al. A situação atual do mercado da saúde suplementar no Brasil e apontamentos para o futuro. Ciência \& Saúde Coletiva. 2008;13:1421-30.

ANS. Rol de Procedimentos e Eventos em Saúde - 2016. 2016.

ANVISA. Cimzia (bula do medicamento). UCB Biopharma 2016.

Azevedo E. Os desafios das operadoras de planos de saúde de autogestão em um cenário de envelhecimento populacional e cronificação de doenças UNIDERP. 2010.

Bernell O, Lapidus A, Hellers G. Risk factors for surgery and postoperative recurrence in Crohn's disease. Annals of surgery. 2000;231(1):38-45.

Blackhouse G, Assasi N, Xie F, Marshall J, Irvine EJ, Gaebel K, et al. Canadian cost-utility analysis of initiation and maintenance treatment with antiTNF-a drugs for refractory Crohn's disease. Journal of Crohn's and Colitis. 2012;6(1):77-85

Bodger K. Cost effectiveness of treatments for inflammatory bowel disease. PharmacoEconomics. 2011;29(5):387-401.
Bodger K, Kikuchi T, Hughes D. Cost-effectiveness of biological therapy for Crohn's disease: Markov cohort analyses incorporating United Kingdom patient-level cost data. Alimentary Pharmacology and Therapeutics. 2009;30(3):265-74.

Brasil. Ministério da Saúde. Secretaria de Ciência, Tecnologia e Insumos Estratégicos. Diretrizes Metodológicas: estudos de avaliação econômica de tecnologias em saúde. 2009.

Burgos-Vargas R, Catoggio LJ, Galarza-Maldonado C, Ostojich K, Cardiel $\mathrm{MH}$. Current therapies in rheumathoid arthritis: A Latin American perspective. Reumatol Clin. 2013; 9(2):106-112.

Carter MJ, Lobo A, Travis SP. Guidelines for the management of inflammatory bowel disease in adults. Gut. 2004(0017-5749 (Print).

Ekbom A, Blomqvist P. Cost to society of Crohn's disease. Research and Clinical Forums. 1998;20(3):33-9.

Feagan BG, Panaccione R, Sandborn WJ, D'Haens GR, Schreiber S, Rutgeerts $P J$, et al. Effects of adalimumab therapy on incidence of hospitalization and surgery in Crohn's disease: Results from the CHARM study. Gastroenterology. 2008;135(5):1493-9.

Joshua-Gotlib S, Coyne K, Kimel M, Danilewitz M, Thompson C. Evaluation of the Burden of Illness in Patients with Mild to Moderate Crohn's disease. Drug Benefit Trends. 2004;16(12):600-9.

Kaplan GG, Hur C, Korzenik J, Sands BE. Infliximab dose escalation vs. initiation of adalimumab for loss of response in Crohn's disease: A cost-effectiveness analysis. Alimentary Pharmacology and Therapeutics. 2007;26(11-12):1509-20.

Lindsay J, Punekar YS, Morris J, Chung-Faye G. Health-economic analysis: Cost-effectiveness of scheduled maintenance treatment with infliximab for Crohn's disease - Modelling outcomes in active luminal and fistulizing disease in adults. Alimentary Pharmacology and Therapeutics. 2008;28(1):76-87.

Loftus EV, Jr., Schoenfeld P, Sandborn WJ. The epidemiology and natural history of Crohn's disease in population-based patient cohorts from North America: A systematic review. Alimentary pharmacology \& therapeutics. 2002;16(1):51-60.

Loftus EV, Jr., Silverstein MD, Sandborn WJ, Tremaine WJ, Harmsen WS, Zinsmeister AR. Crohn's disease in Olmsted County, Minnesota, 1940-1993: Incidence, prevalence, and survival. Gastroenterology. 1998;114(6):1161-8.

Miyazaki Y, Harada T, Akase T, Arakawa I, Inoue T. Cost-minimization analysis of sequence changes between FOLFIRI and FOLFOX6 therapy for advanced colorectal cancer in Japan. Clinical therapeutics. 2009;31 Pt 2:2433-41.

Nikfar S, Ehteshami-Afshar S, Abdollahi M. Is Certolizumab Pegol Safe and Effective in the Treatment of Patients with Moderate to Severe Crohn's Disease? A Meta-analysis of Controlled Clinical Trials. Iran Red Crescent Med J. 2013;15(8):668-75.

Peyrin-Biroulet L, Deltenre P, de Suray N, Branche J, Sandborn WJ, Colombel JF. Efficacy and safety of tumor necrosis factor antagonists in Crohn's disease: Meta-analysis of placebo-controlled trials. 2008;6(6):644-53.

Sandborn W, Feagan B, Stoinov S, Honiball P, Rutgeerts P, Manson D, et al. Certolizumab Pegol for the Treatment of Crohn's Disease. New England Journal of Medicine. 2007(357):228-38.

Shanahan F. Crohn's disease. Lancet. 2002;359(9300):62-9.

Shao LM, Chen MY, Chen QY, Cai JT. Meta-analysis: The efficacy and safety of certolizumab pegol in Crohn's disease (Structured abstract). 2009. p. 605-14.

Shivananda S, Lennard-Jones J, Logan R, Fear N, Price A, Carpenter L, et al. Incidence of inflammatory bowel disease across Europe: Is there a difference between north and south? Results of the European Collaborative Study on Inflammatory Bowel Disease (EC-IBD). Gut. 1996;39(5):690-7. 
Silverstein MD, Loftus EV, Sandborn WJ, Tremaine WJ, Feagan BG, Nietert PJ, et al. Clinical course and costs of care for Crohn's disease: Markov model analysis of a population-based cohort. Gastroenterology. 1999;117(1):49-57.

Singh S, Garg SK, Pardi DS, Wang Z, Murad MH, Loftus EV, Jr. Comparative efficacy of biologic therapy in biologic-naive patients with Crohn's disease: A systematic review and network meta-analysis. 2014;89(12):1621-35.

Stidham RW, Lee TC, Higgins PD, Deshpande AR, Sussman DA, Singal AG, et al. Systematic review with network meta-analysis: The efficacy of antiTNF agents for the treatment of Crohn's disease. 2014;39(12):1349-62.

Trallori G, Palli D, Saieva C, Bardazzi G, Bonanomi AG, d'Albasio G, et al. A population-based study of inflammatory bowel disease in Florence over 15 years (1978-92). Scandinavian journal of gastroenterology. 1996;31(9):892-9.
Tundia N, Kotze PG, Serrano JR, de Abreu MM, Skup M, Macaulay D, Signorovitch J et al. Economic impact of expanded use of biologic therapy for the treatment of rheumathoid arthritis and Crohn's disease in Argentina, Brazil, Colombia and Mexico. J Med Econom. 2016; 19 (12): 1187-1199.

Wolters FL, Russel MG, Sijbrandij J, Schouten LJ, Odes S, Riis L, et al. Crohn's disease: Increased mortality 10 years after diagnosis in a Europe-wide population based cohort. Gut. 2006;55(4):510-8. 